\title{
ANALISIS PENGARUH KENDARAAN PARKIR DI BADAN JALAN SEBAGAI HAMBATAN SAMPING TERHADAP KINERJA RUAS JALAN MAHONI KOTA BENGKULU
}

\author{
Samsul Bahri ${ }^{1)}$, Rio Saputra ${ }^{2)}$, Yuzuar Afrizal ${ }^{3)}$ \\ ${ }^{122) 3)}$ Program Studi Teknik Sipil, Fakultas Teknik UNIB, Jl. W. R. Supratman, \\ Kandang Limun, Bengkulu 38371, Telp. (0736)344087 \\ email: riosaputra839@gmail.com
}

\begin{abstract}
Abstrak
Parkir pada badan jalan menjadi salah satu penyebab kemacetan lalu lintas, oleh karena itu penanganan parkir di badan jalan menjadi sangat penting dan mempunyai dampak positif terhadap pemecahan masalah kemacetan lalu lintas. Tujuan dari penelitian ini adalah mengetahui pengaruh kendaraan parkir di badan jalan terhadap kinerja ruas Jalan Mahoni Kota Bengkulu. Metode dan teknik pengumpulan data meliputi survai geometrik jalan, survai volume lalu lintas, survai hambatan samping dan survai kecepatan. Untuk mendapatkan data pada penelitian ini dilakukan dengan cara merekam keadaan ruas jalan dan menghitung jumlah kendaraan yang melintasi ruas jalan melalui hasil rekaman. Data yang dihasilkan pada jam puncak berupa kapasitas $1544,076 \mathrm{smp} / \mathrm{jam}$ volume lalu lintas 1281,2 $\mathrm{sm} / \mathrm{jam}$ dengan derajat kejenuhan 0,83 berada pada tingkat pelayanan D yang artinya mendekati arus yang tidak stabil, kecepatan rendah. Nilai DS berada di atas nilai derajat kejenuhan yang disyaratkan oleh MKJI yaitu DS $<0,75$. Perlu dilakukan alternatif penanggulangan dengan cara memindahkan parkir yang berada pada Jalan Mahoni menghasilkan kapasitas 2218,5 smp/jam dan derajat kejenuhan 0,50 dengan tingkat pelayanan $\mathrm{C}$ yang artinya arus stabil dan kecepatan dikontrol oleh lalu lintas.
\end{abstract}

Kata kunci: parkir, arus lalu lintas, tingkat pelayanan

\begin{abstract}
Parking on the road body is one of the causes of traffic congestion, therefore the handling of parking on the road becomes very important and has a positive impact on solving traffic congestion problems. The purpose of this study was to determine the effect of parking vehicles on the road body on the performance of the Mahoni Street in Bengkulu City. Data collection methods and techniques include road geometric surveys, traffic volume surveys, side barriers and speed surveys. To get the data in this study is done by recording the state of the road and calculating the number of vehicles that cross the road through the recording.Data generated at peak hours in the form of a capacity of 1544,076 smp/hour traffic volume of $1281.2 \mathrm{sm} /$ hour with a degree of saturation of 0.83 is at the level ofservice $D$ which means approaching an unstable current, low speed. DS value is above the degree of saturation required by MKJI, namely DS $<0.75$. It is necessary to do alternative countermeasures by moving the parking located on Mahoni Street resulting in a capacity of $2218.5 \mathrm{smp} / \mathrm{hour}$ and a saturation degree of 0.50 with level ofservice $C$ which means that the current is stable and the speed is controlled by traffic.
\end{abstract}

Keywords: parking, flow of traffic, level of service 


\section{PENDAHULUAN}

Parkir merupakan prasarana yang penting dalam sistem transportasi. Parkir menurut Manual Kapasitas Jalan Indonesia (MKJI, 1997) yaitu dimana suatu kendaraan berhenti untuk sesaat atau dalam jangka waktu yang cukup lama. Berdasarkan lokasi, parkir dibedakan menjadi 2 yaitu parkir di suatu lahan tertutup (off street) dan parkir di badan jalan (on street).

Hambatan samping menurut Manual Kapasitas Jalan Indonesia (MKJI, 1997) merupakan aktivitas samping jalan yang sering menimbulkan pengaruh yang cukup signifikan. Tingginya aktivitas samping jalan berpengaruh besar terhadap kapasitas dan kinerja jalan pada suatu wilayah perkotaan. Hambatan samping diantaranya adalah pejalan kaki, penyeberang jalan, kendaraan berjalan lambat (becak, sepeda, kereta kuda), kendaraan berhenti sembarangan (angkutan kota, bus dalam kota), parkir di badan jalan (on street parking), dan kendaraan keluar-masuk pada aktivitas parkir di badan jalan.

Salah satu penyebab tingginya aktivitas samping jalan yaitu disebabkan oleh perkembangan aktivitas penduduk yang setiap tahunnya tumbuh di wilayah perkotaan. Perkembangan aktivitas penduduk berpengaruh besar terhadap penyediaan fasilitas dan pemenuhan kebutuhan. Namun hal tersebut belum diimbangi oleh penyediaan sarana dan prasarana transportasi yang memadai sehingga munculnya permasalahan transportasi pada ruas jalan perkotaan.

Jalan Mahoni termasuk dalam jalan kelas III, Jalan Mahoni terdiri dari 2 jalur dan 2 arah. Kawasan Jalan Mahoni merupakan salah satu pusat pendidikan, perkantoran, dan Rumah Sakit Raflessia Kota Bengkulu. Jalan Mahoni memiliki lalu lintas yang cukup padat dan banyak kendaraan roda empat yang parkir di badan jalan. Untuk mengukur kinerja ruas Jalan Mahoni yang disebabkan oleh Permasalahan parkir di ruas jalan tersebut, perlu dilakukan penelitian.

\section{Parkir}

Parkir adalah keadaan tidak bergerak suatu kendaraan yang bersifat sementara karena ditinggalkan oleh pengemudinya. Secara hukum dilarang untuk parkir di tengah jalan raya, namun parkir di sisi jalan umumnya diperbolehkan. pengertian parkir adalah setiap kendaraan yang berhenti pada tempattempat tertentu baik yang dinyatakan dengan rambu lalu lintas ataupun tidak, serta tidak semata-mata untuk kepentingan menaikkan atau menurunkan orang/barang (MKJI, 1997).

\section{Parkir di badan jalan}

Parkir di badan jalan (on street parking) adalah fasilitas parkir yang menggunakan sebagian badan jalan atau ruas jalan. Pada sistem parkir di badan jalan ini harus mempertimbangkan tempat parkir yang terarah (Dirjen Perhubungan Darat, 1998).

\section{Volume lalu lintas}

Volume lalu lintas adalah jumlah kendaraan yang melewati titik per satuan waktu pada lokasi tertentu. Untuk mengukur jumlah arus lalu lintas, biasanya dinyatakan dalam smp/jam (MKJI, 1997).

Untuk menghitung volume lalu lintas jumlah kendaraan dibagi dengan faktor EMP. Ekivalensi mobil penumpang (EMP) yaitu faktor konversi berbagai jenis kendaraan dibandingkan dengan mobil penumpang atau kendaraan ringan lainnya sehubungan dengan dampaknya pada perilaku lalu lintas. Tabel 1 adalah nilai Ekivalensi mobil penumpang (EMP) menurut MKJI (1997).

Tabel 1. Nilai EMP

\begin{tabular}{|l|c|}
\hline Jenis Kendaraan & Nilai EMP \\
\hline LV & 1 \\
HV & 1,3 \\
MC & 0,5 \\
\hline
\end{tabular}

Sumber: MKJI, 1997 


\section{Kapasitas}

Kapasitas didefinisikan sebagai arus maksimum yang dapat dipertahankan persatuan jam yang melewati suatu titik di jalan dalam kondisi yang ada. Kapasitas merupakan ukuran kinerja jalan pada kondisi yang bervariasi, dapat ditetapkan pada suatu lokasi tertentu atau pada suatu jaringan jalan yang sangat komplek dan dinyatakan dengan satuan smp/jam. Kapasitas akan menjadi lebih tinggi apabila suatu jalan mempunyai kondisi yang lebih baik dari kondisi standar, sebaliknya bila suatu jalan kondisinya lebih buruk dari kondisi standar maka kapasitasnya akan menjadi lebih rendah. Persamaan untuk menentukan kapasitas ruas jalan dapat dilihat pada persamaan (1) berikut:

$\mathrm{C}=\mathrm{C}_{\mathrm{O}} \times \mathrm{FC}_{\mathrm{W}} \times \mathrm{FC}_{\mathrm{SP}} \times \mathrm{FC}_{\mathrm{SF}} \times \mathrm{FC}_{\mathrm{CS}}$

Dimana:

C $=$ Kapasitas Jalan (smp/jam)

Co = Kapasitas Dasar (smp/jam)

$\mathrm{FCw}=$ Faktor lebar Jalur

FCsp = Faktor Pemisah Arah

FCsf = Faktor Hambatan Samping

FCcs $=$ Faktor Penyesuaian Kota

\section{Derajat kejenuhan (DS)}

Derajat kejenuhan (DS) didefinisikan sebagai rasio arus terhadap kapasitas, digunakan sebagai faktor utama dalam penentuan tingkat kinerja jalan. Nilai DS menunjukkan apakah segmen jalan tersebut mempunyai masalah kapasitas atau tidak. Derajat kejenuhan dihitung dengan menggunakan arus dan kapasitas dinyatakan dalam smp/jam. Untuk menghitung derajat kejenuhan digunakan persamaan (2) berikut:

$$
\mathrm{DS}=\frac{Q}{C}
$$

Dengan:

DS $=$ Derajat kejenuhan

$\mathrm{C}=$ Kapasitas (smp/jam)

$\mathrm{Q}=$ Volume (smp/jam)

\section{Tingkat pelayanan jalan}

Tingkat pelayanan jalan didefinisikan sejauh mana kemampuan jalan menjalankan fungsinya. Atas dasar itu pendekatan tingkat pelayanan dipakai sebagai indikator tingkat kinerja jalan (level of service). Level of service merupakan suatu ukuran kualitatif yang menggunakan kondisi operasi lalulintas pada suatu potongan jalan. Dengan kata lain tingkat pelayanan jalan adalah ukuran yang menyatakan kualitas pelayanan yang disediakan oleh suatu jalan dalam kondisi tertentu. Nilai tingkat pelayanan jalan (level of service) dapat dilihat pada Tabel 2.

Tabel 2. Nilai Tingkat Pelayanan Jalan

\begin{tabular}{|c|c|}
\hline Tingkat Pelayanan & Derjat Kejenuhan \\
\hline $\mathrm{A}$ & $0,00-0,20$ \\
\hline $\mathrm{B}$ & $0,20-0,44$ \\
\hline $\mathrm{C}$ & $0,45-0,74$ \\
\hline $\mathrm{D}$ & $0,75-0,84$ \\
\hline $\mathrm{E}$ & $0,85-1,00$ \\
\hline $\mathrm{F}$ & $>1,00$ \\
\hline
\end{tabular}

Sumber: Morlock, 1984

\section{Penelitian terkait parkir pada badan jalan}

Penelitian Gea dan Harianto (2011) memberikan informasi bahwa pengaruh parkir pada badan jalan di ruas jalan besar di kawasan pertokoan menyebabkan berkurangnya lebar jalur lalu lintas efektif sebesar 1,6 meter sehingga terjadi penurunan kapasitas ruas jalan dari 2244,60 smp/jam menjadi 1535,31 smp/jam pada hari kerja, dan 1654,72 smp/jam pada hari libur.

Syaputra, Sebayang dan Herianto (2015) melaporkan bahwa pengaruh hambatan samping terhadap kinerja lalu lintas jalan nasional menghasilkan nilai derajat kejenuhan tertinggi yaitu 1,01 dengan jumlah volume kendaraan sebesar 1395 smp/jam dan kapasitas ruas jalan 1384 smp/jam. 
Yany, Farida, dan Walujodjati (2016) melakukan penelitian pengaruh hambatan samping terhadap kinerja ruas jalan dengan hasil yaitu pengaruh parkir pada badan jalan merupakan masalah lalu lintas yang harus diselesaikan karena menyebabkan berkurangnya lajur lalu lintas efektif sebesar 4,2 meter, sehingga menimbulkan penurunan kapasitas jalan dari 1.387 smp/jam menjadi 1.281 smp/jam $(7,6 \%)$ pada hari kerja dan $1.221 \mathrm{smp} / \mathrm{jam}(12 \%)$ pada hari libur.

\section{METODE PENELITIAN}

Penelitian ini dilakukan pada Jalan Mahoni Kota Bengkulu dengan meninjau hambatan samping yaitu parkir pada badan jalan. Pengumpulan data dilakukan melalui survai dan rekaman video di Jalan Mahoni Kota Bengkulu, Survai terdiri dari beberapa bagian yaitu urvai geometrik jalan, survai survei arus lalu lintas, dan hambatan samping.

\section{HASIL DAN PEMBAHASAN}

\section{Hasil survai arus lalu lintas}

Dari hasil survai yang dilakukan selama 3 hari, menunjukkan bahwa kendaraan yang melewati ruas jalan di pagi hari jumlahnya di atas 40\%. Hal ini dapat dilihat pada Gambar 1.

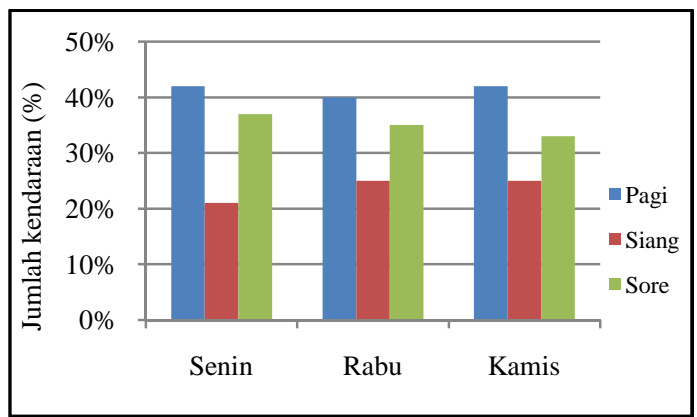

Gambar 1. Diagram Volume Kendaraan

Dari Gambar 1 diketahui, arus lalu lintas terpadat pada pagi hari terjadi pada hari Senin pukul $07.00-07.15$ yaitu $42 \%$. Arus lalu lintas terpadat pada siang hari terjadi pada hari Rabu pukul 13.00 - 13.15 WIB yaitu $25 \%$. Arus lalu lints terpadat pada sore hari terjadi pada hari Senin pukul 15.30 15.45 WIB yaitu $37 \%$.

\section{Hasil survai hambatan samping}

Dari hasil survai yang dilakukan selama 3 hari dapat dilihat diagram hambatan samping kendaraan pada Gambar 2.

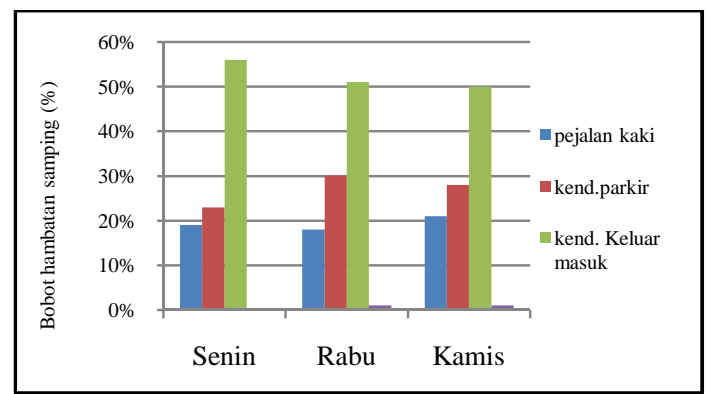

Gambar 2. Diagram Hambatan samping

Dari Gambar 2, diketahui, jumlah hambatan samping tertinggi pada hari Senin dengan bobot hambatan samping kendaraan keluar masuk 56\% kendaraan parkir 23\% dan pejalan Kaki $19 \%$.

\section{Kapasitas}

Perhitungan kapasitas dilakukan pada setiap jam puncak selama periode pengamatan, yaitu pagi, siang, dan sore hari. Berikut adalah contoh perhitungan kapasitas jalan pada saat jam puncak Senin:

$$
\begin{aligned}
\mathrm{C} & =\mathrm{C}_{\mathrm{O}} \times \mathrm{FC}_{\mathrm{W}} \times \mathrm{FC}_{\mathrm{SP}} \times \mathrm{FC}_{\mathrm{SF}} \times \mathrm{FC}_{\mathrm{CS}} \\
& =2900 \times 1,25 \times 1 \times 0,78 \times 0,9 \\
& =2218,5 \mathrm{smp} / \mathrm{jam}
\end{aligned}
$$

Tabel 3. Hasil Perhitungan Kapasitas

\begin{tabular}{|c|c|c|}
\hline Hari & $\begin{array}{c}\text { Periode } \\
(\mathrm{WIB})\end{array}$ & $\begin{array}{c}\text { Kapasitas } \\
(\mathrm{smp} / \mathrm{jam})\end{array}$ \\
\hline \multirow{4}{*}{ Senin } & $07.00-07.15$ & 2544,75 \\
\cline { 2 - 3 } & $12.30-12.45$ & 3034,125 \\
\cline { 2 - 3 } & $15.30-15.45$ & 2805,75 \\
\hline \multirow{3}{*}{ Rabu } & $07.00-07.15$ & 2805,75 \\
\cline { 2 - 3 } & $13.00-13.15$ & 3034,125 \\
\cline { 2 - 3 } & $15.30-15.45$ & 2936,25 \\
\hline \multirow{4}{*}{ Kamis } & $07.00-07.15$ & 2544,75 \\
\cline { 2 - 3 } & $13.00-13.15$ & 3034,125 \\
\cline { 2 - 3 } & $15.30-15.45$ & 2936,25 \\
\hline
\end{tabular}




\section{Derajat kejenuhan}

Nilai derajat kejenuhan ini merupakan perbandingan arus lalu lintas yang melintas terhadap kapasitas total Jalan Mahoni. Nilai tersebut akan menunjukkan baik atau buruknya kinerja jalan berdasarkan persyaratan MKJI 1997. Berikut contoh perhitungan derajat kejenuhan Jalan Mahoni pada hari Senin:

$\mathrm{DS}=\frac{Q}{C}$

$\mathrm{DS}=\frac{1281,2}{1544,076}=0,83$

Dari perhitungan derajat kejenuhan dengan nilai 0,83 , kondisi lalu lintas pada pagi hari berada pada tingkat pelayanan D berada di atas nilai derajat kejenuhan yang disyaratkan oleh MKJI yaitu DS < 0,75 . Melihat posisi Jalan Mahoni merupakan pusat perkantoran, sekolah dan kesehatan, ditambah kemungkinan berkembangnya pertumbuhan kendaraan di Kota Bengkulu, maka dengan alasan ini diperkirakan dalam beberapa tahun ke depan Jalan Mahoni akan mengalami kemacetan lalu-lintas. Untuk mengatasi masalah ini akan dilakukan beberapa alternatif pemecahan masalah yaitu:

Alternatif I: Memindahkan parkir yang berada pada Jalan Mahoni

Perhitungan kapasitas :

$$
\begin{aligned}
\mathrm{C} & =\mathrm{C}_{\mathrm{O}} \times \mathrm{FC}_{\mathrm{W}} \times \mathrm{FC}_{\mathrm{SP}} \times \mathrm{FC}_{\mathrm{SF}} \times \mathrm{FC}_{\mathrm{CS}} \\
& =2900 \times 1,25 \times 1 \times 0,78 \times 0,9 \\
& =2218,5 \mathrm{smp} / \mathrm{jam}
\end{aligned}
$$

Perhitungan derajat kejenuhan

$\mathrm{DS}=\frac{Q}{C}$

$\mathrm{DS}=\frac{1281,2,2}{2544,75}=0,50$

Dari hasil analisi pada alternatif I, kapasitas yang awalnya 1544,076 smp/jam, meningkat menjadi 2218,5 smp/jam. derajat kejenuhan 0,83 dengan tingkat pelayanan $\mathrm{D}$ menurun menjadi 0,50 dengan tingkat pelayan $\mathrm{C}$ yang artinya arus stabil dan kecepatan dikontrol oleh lalu lintas. Nilai DS 0,5 sudah memenuhi syarat MKJI 1997 yaitu DS < 0,75 .

Alternatif II: Menjadikan parkir pada Jalan Mahoni menjadi satu sisi

Perhitungan kapasitas:

$$
\begin{aligned}
\mathrm{C} & =\mathrm{C}_{\mathrm{O}} \times \mathrm{FC}_{\mathrm{W}} \times \mathrm{FC}_{\mathrm{SP}} \times \mathrm{FC}_{\mathrm{SF}} \times \mathrm{FC}_{\mathrm{CS}} \\
& =2900 \times 1,07 \times 1 \times 0,78 \times 0,9 \\
& =2178,306 \mathrm{sinp} / \mathrm{jam}
\end{aligned}
$$

Perhitungan derajat kejenuhan:

$\mathrm{DS}=\frac{Q}{C}$

$\mathrm{DS}=\frac{1281,2}{2178,306}=0,58$

Dari hasil analisis pada alternatif II, kapasitas yang awalnya 1544,076 smp/jam, meningkat menjadi 2178,306 smp/jam. derajat kejenuhan 0,83 dengan tingkat pelayanan $\mathrm{D}$ menurun menjadi 0,58 dengan tingkat pelayan C. Nilai DS 0,58 sudah memenuhi syarat MKJI 1997yaitu DS < 0,75 .

\section{KESIMPULAN}

Berdasarkan hasil analisis dan pembahasan maka dapat disimpulkan:

1. Dengan adanya parkir pada badan jalan mengurangi lebar jalur efektif sehingga mempengaruhi kapasitas Jalan Mahoni. Kapasitas pada jam puncak pagi hari tanpa adanya parkir yaitu 2218,05 smp/jam, dengan adanya parkir berkurang menjadi 1544,076 smp/jam. Kinerja ruas Jalan Mahoni pada saat jam puncak pengamatan ditentukan berdasarkan derajat kejenuhan. kinerja ruas Jalan Mahoni pada saat jam puncak pagi berada pada level D yang artinya lalu lintas mendekati arus tidak stabil dan kecepatan rendah. Nilai DS yaitu 0,83 berada di atas nilai derajat kejenuhan yang ditentukan MKJI 1997 yaitu DS < 0,75 .

2. Jika ditinjau dari faktor hambatan samping yang paling mempengaruhi kinerja ruas Jalan Mahoni yaitu 
kendaraan parkir dan kendaraan keluar masuk bangunan.

3. Hasil analisis yang dilakukan pada alternatif I yaitu memindahkan parkir yang berada pada jalan mahoni didapatkan nilai kapasitas 2218,5 smp/jam. derajat kejenuhan 0,50 dengan tingkat pelayan $\mathrm{C}$ yang artinya arus stabil dan kecepatan dikontrol oleh lalu lintas. Nilai DS 0,5 sudah memenuhi syarat MKJI 1997yaitu DS < 0,75. Hasil alternatif II, kapasitas 2178,306 smp/jam, 0,58 dengan tingkat pelayan $\mathrm{C}$ yang artinya arus stabil dan kecepatan dikontrol oleh lalu lintas. Nilai DS 0,58 sudah memenuhi syarat MKJI 1997 yaitu DS $<0,75$.

\section{DAFTAR PUSTAKA}

Direktorat Jenderal Bina Marga,1997. Manual Kapasitas Jalan Indonesia. Departemen Pekerjaan Umum RI,Jakarta.

Dirjen Perhubungan Darat, 1998 Pedoman Perencanaan dan Pengoperasian
Fasilitas
Parkir.
Departemen
Perhubungan Republik Indonesia, Jakarta.

Gea, M.S.A, dan Herianto, J, 2011, Analisi Kinerja Ruas Jalan Akibat Parkir Pada Badan Jalan (Studi Kasus : Pasar dan Pertokoan Jalan Beasar Delitua), Jurnal Teknik Sipil, Vol.2 No. 3, Desember 2011.

Morlock, K.E, 1984. Pengantar Teknik dan Perencanaan Transportasi. Erlangga, Jakarta.

Syaputra, R, Sebayang, S, dan Herianto, D, 2015, Pengaruh Hambatan Samping Terhadap Kineja Lalu Lintas Jalan Nasional, Jurnal Teknik Sipil, Vol.3 No. 3, September 2015.

Yany, R.M, Farida, I, dan Walujodjati, E, 2016, Pengaaruh Parkir Pada Badan Jalan Terhadap Kinerja Ruas Jalan (Studi Kasus: Ruas Jalan Ciledug Kota Garut), Jurnal Teknik Sipil, Vol.14 No. 1, Februari 2016. 
ISSN 2086-9045 